\title{
The Performance Of Islamic Banking With Maqashid Index
}

\author{
Isna ardila ${ }^{1}$, Novi Fadhila ${ }^{2}$, Rini Astuti ${ }^{3}$ and Nadia Ika Purnama ${ }^{4}$ \\ \{isna.ardila@gmail.com ${ }^{1}$ \} \\ 1,2,3,4 University of Muhammadiyah Sumatera Utara, Jalan Kapten Mukhtar Basri No. 3 Medan
}

\begin{abstract}
This study aims to measure the performance of Islamic banks based on the Maqashid Sharia Index. This research is a descriptive research. The study used four samples of Islamic banks, namely Bank Muamalat Indonesia, Bank Syariah Mandiri, Bank Rakyat Indonesia Syariah, and Bank Negara Indonesia Syariah. The research data used was the annual report in 2015-2017. The analytical method used in this research was the Maqasid Sharia Index with three indicators, namely Educating Individual, establishing Justice, Maslahah/Justice. The results of the study showed that Islamic banks had implemented the three purposes and objectives of sharia, except that the results of performance each year vary, no one is able to realize high performance in all ratios.
\end{abstract}

Keywords : Maqashid Index, Performance Measurement

\section{Introduction}

The development of Islamic Bank in Indonesia started to improve and develop between the already existing conventional banks. The presence of Islamic banks is one solution for people, especially Muslims who want to avoid the practice of banks that use the system of interest or usury. It's not just Muslims who became the bank's Sharia, but also non-Muslim Customers interested in Islamic banking products. So far, the development of Islamic banking performance is reflected in the positions of the Islamic Bank assets recorded a growth of $20.65 \%$ on-year at the end of February 2018 to 429.36 trillion. Meanwhile, financing is $14.76 \%$ yoy 289.99 trillion. In this process, the measurement of performance levels on Islamic banking can determine their performance measurement and monitoring system (Antonio, Sanrego and Taufiq, 2012). The performance of Bank is important for all parties; depositors, bank managers, regulators, and competitive markets (Qasim et al., 2017). The performance of the bank provides a signal for investors-depositors withdraw funds from an investment or withdraw funds from the bank (Qasim et al., 2017). Conventional banks and Islamic banks in their role as financial institutions compete for clients and investors (Rabaa and Younes, 2016). The characteristics of Islamic banking in general surgery is based on the principle of mutually beneficial partnerships with the community as well as bank (Saoqi, 2017).

Banking performance measurement is generally limited to financial ratios such as camels (capital, assets, management, earning, liquidity, market risk sensitivity), EVA (Economic Value Added), the Payback period of the Balance Scorecard and the others still conventional. (Bedoui, 2012) divided the performance of Islamic banking in three categories: performance, general performance trends and global performance. Measurement of the performance of Islamic banks should not just focus on financial performance that has been used by conventional banks only profit oriented, but also need to measure performance based on the intent and purpose of the Shariah, namely pay heed to the principles of Islam which is free 
from the practice of usury or interest, maysir or gambling, and gharar (uncertainty). Therefore, different from conventional banking Islamic banking in both theory and practice requires a paradigm shift in terms of measuring the performance of those who are not only limited to financial ratios (stakeholder-oriented) (Antonio, Sanrego and Taufiq, 2012). According to (Mohammed and Razak, 2008) using the same conventional sizes to measure banking Islam there is incompatibility between this conventional performance indicators and objectives broad Islamic banking. Islamic banks, as a business entity, not only are required to pursue profit, but must also account for all activities to God Almighty Islamic sharia is divided into three groups, namely the belief (creed), worship and morality (akhlaq). Law as an integral part which can not be separated from the Sharia. Application of Sharia aims to achieve benefits (maslahah) and provide protection and benefits to humans to avoid kemudharatan (mafsadah) to protect humans from damage (Afif Muamar, 2017). Islamic Sharia itself has a purpose in accordance with the principles of human rights (Towadi, 2017). Religious studies will give life purpose and moral values that can support the welfare and development of the measurement (Salman Syed Ali, 2014).

Maqasid index is a measurement performance for Islamic banking that is not only focused on profit and other financial measures generally, but includes other values of banks that reflects the size of the nonprofit benefits in accordance with the purposes and principles of the Shariah. The goal of Islamic banks are not restricted to the financial aspects but should also pay attention to other aspects such as social and environmental aspects. The development of Syariah index Trends based on the difference in the use of conventional performance indicators in Islamic banking. Sharia banking performance measurement by using a variable that shows the percentage of Islamic trends better than conventional banking performance measurement (Mohammed and Razak, 2008). Maqasid Sharia index was developed with three main factors, namely, educating individuals, establishing justice and maslahah.

Performance measurement using Islamic Trends index is still very minimal by Islamic banks. Where the majority of the Muslim community should make this easier performance measurements to be performed, because the religious foundation, so deeply rooted in people's lives. But in fact, much of the criticism directed at Islamic banks which tend to be oriented towards profit, which is not based on social objectives when seen from the standpoint of Islam maqasid (Sudrajat, 2015) shows that Islamic banks should re-evaluate the objectives of Syariah Bank really bring good in accordance with Shariah (Soleh, 2016) shows that there is still a lack of achievement in the performance of Islamic banks and Islamic finance Maqasid (Harningtyas, 2015). Islamic finance is considered part of the Islamic economic system oriented social inherent (Ahmed, 2011).

From the results of several studies on the above, it can be seen that generally Indonesia community did not approve the existence of interest, stating that interest is included in the riba and therefore is something that violates the law, and the General level of trust Indonesia Islamic banks are relatively high. However, most people still relatively Indonesia cannot distinguish between the concept and the practice of Islamic banking, so there are still many people who think that Islam is the same bank as the Bank conventional and finally assume that profit from islamic bank is the same with interest from a conventional Bank (Prasetyowati and Handoko, 2016). With a kind of problems that have been expressed, this study will measure the performance of Islamic banks not only using financial performance analysis, but using measurements that are suitable for Islamic banking, namely the maqashid sharia index. The Maqashid Sharia Index is divided into three categories; three maqashid can be changed into 9 dimensions and 10 elements. Ten elements are changed to a performance ratio. Educating individuals in the first Maqashid means developing knowledge and expertise to individuals so 
that spiritual values increase. Islamic banks must design education and training programs with moral values so that they will be able to increase their knowledge and expertise to employees. The Bank also provides information to stakeholders that the products offered are in accordance with sharia.

The core of the term Islamic Trends is aware of good and evil, refuse or draw benefits and denying the losses. the term commensurate with the core trends of Sharia is maslahah, because Islamic law provisions should lead to benefits (Sudrajat, 2015). Measurement of the performance of Islamic banks using the ratio-financial ratio adaptation of conventional banking as has been done by many researchers have not been able to show actual Islamic Bank performance appraisal as an economic subsystem Islam aims to realize the balance of Justice and of society as a manifestation of the purpose of the Sharia (Islamic trends). So the most Islamic banks seem to be oriented to profit (profit-oriented) not based on social objectives (Sudrajat, 2015). In connection with this (Mohammed and Razak, 2008) developed a model of performance measurement trends based on Islamic Sharia banks adapted from formulas maqasid Sharia possessed by Abu Zahrah (1997) classifies the maqasid Islamic concept became : 1) educate individuals, 2) enforcing justice, and 3) maintain the benefits. using methods now to break the Islamic concept of maqashid be indicators that have elements that then the proxy by financial ratio performance of Islamic banks resulting in a maqashid sharia index is achieved by Islamic banks (Sudrajat, 2015) .

\section{Method Of Research}

Approach this research was descriptive Research. The data used in this research was secondary data taken from Annual financial reports of four Islamic banks for the period of the year 2014-2016.

Below this the maqashid Shariah Index indicator was being taken to meet the research:

1. Maqashid Index I (Educating Individual), consists of 4 ratios (R1-R4) namely, Education Expense / Total Expense (R1 / R11), Research Expense / Total Expense (R2 / R12), Training Fee / Total Expense (R3 / R13) and Promotion / Total Expense (R4 / R14).

2. Maqashid Index II (Establishing Justice), terdiri dari 3 rasio (R5-R7) namely Profit Equalization Reserves (PER)/ Net Income or Investment Income (R5/R21 $)$, Mudharabah and Musyarakah / Total Investment Financing (R6 / R22), and Free Interest Income / Total Revenue (R7 / R23). This research only uses the ratio of Musharabah and Musyarakah / Total Investment Financing (R6 / R22).

3. Maqashid Index III (Maslahah / Justice), consisting of 3 ratios (R8-R10) namely Net Profit / Total Assets (R8 / R31), Zakah / Net Asset (R9 / R32), and Investment in the Real Sector / Investment Total (R10 / R33).

This study used the quantitative method of The Simple Additive Weighting (SAW) or the weighted addition method. The basic concept of the SAW method was to find the sum weighted from rating of each destination in all attributes was called Multiple Attribute Decision Making (MADM). This method required the decision maker to determine the goal weight and the ratio that matched their attributes. Attribute was a measure of the performance of a sample to be measured. The final score of Maqashid Sharia Index was obtained from the sum of the three main Performance Indicators (PI), including PI 1, PI 2 and PI 3. PI 1 represented the creation of individual education goals. PI 2 represented the realization of justice. PI 3 represented prosperity. 


\section{Data Analysis And Discussion}

Human resources who have the ability and competitive knowledge is one of the aspects of competition in the banking business. To enhance the skills and expertise of employees, carry out education, research and training programs employees so that they can enhance their professionalism in the workplace. The publicity program is an effort by the company to build public awareness of the existence of Islamic banking. With the aim to create justice, ratio distribution can describe the capabilities of Islamic banks to allocate funds for activities based on justice in the form of maintenance rights between the bank and the customer. These activities are actualized through the distribution of mudharabah and musyarakah financing. The achievement of well-being reflects the bank's ability to realize the prosperity of stakeholders that can be measured by using a ratio of profitability. Profitability ratio affect the overall effectiveness of management as indicated by the size of the profits obtained in the sale and investment activities. The explanation above is the manifestation of the Islamic banking's performance can be measured or assessed using Sharia index trends.

The results of Islamic Banking based on Maqashid Index ratio in 2014-2016 can be seen in the table 1 below:

Table 1. Maqashid Index Performance Ratio 2014

\begin{tabular}{|c|c|c|c|c|c|c|c|c|}
\hline \multirow[t]{2}{*}{ Banks } & \multirow{2}{*}{$\begin{array}{l}\text { Maqashid Index } 1^{\text {st }}(\mathrm{MI} \\
\text { 1) } \\
\mathrm{R} 1^{1}\end{array}$} & \multirow{2}{*}{$\begin{array}{l}\text { (MI 2) } \\
\mathrm{R}^{2} \\
\end{array}$} & \multicolumn{6}{|c|}{ Maqashid Index $3^{\text {rd }}$} \\
\hline & & & $\mathrm{R} 1^{3}$ & $\mathrm{R} 1^{4}$ & $\mathrm{R}^{2}$ & $\mathrm{R}^{1}$ & $\mathrm{R}^{2}{ }^{2}$ & $\mathrm{R}^{3}$ \\
\hline BMI & 0,262 & 0,17 & 0,703 & 3,424 & 50,991 & 0,159 & 0,023 & $\begin{array}{l}68,21 \\
6\end{array}$ \\
\hline BSM & 0,03 & 0,059 & 0,681 & 1,362 & 21,901 & $-0,034$ & 0,005 & $\begin{array}{l}54,81 \\
9\end{array}$ \\
\hline BRIS & 0,022 & 0 & 1,04 & 2,572 & 31,715 & 0,051 & 0,047 & $\begin{array}{l}86,98 \\
2\end{array}$ \\
\hline BNIS & 0,11 & 0 & 2,44 & 5,33 & 16,43 & 1,13 & 0,03 & 44,81 \\
\hline
\end{tabular}

Table 2 . Maqashid Index Performance Ratio 2015

\begin{tabular}{lllllllll}
\hline Banks & $\begin{array}{l}\text { Maqashid Index } 1^{\text {st }} \text { (MI } \\
\text { 1) }\end{array}$ & (MI 2) & \multicolumn{2}{l}{ Maqashid Index $3^{\text {rd }}$} \\
& $\mathrm{R} 1^{1}$ & $\mathrm{R}^{2}$ & $\mathrm{R}^{3}$ & $\mathrm{R}^{4}$ & $\mathrm{R}^{2}$ & $\mathrm{R}^{1}$ & $\mathrm{R}^{2}$ & $\mathrm{R}^{3}$ \\
\hline BMI & 0,2 & 0,179 & 1,715 & 4,170 & 53,835 & 0,19 & 0,003 & 58,643 \\
\hline BSM & 0,019 & 0,045 & 1,202 & 1,373 & 26,261 & 0,545 & 0,016 & 51,46 \\
\hline BRIS & 18,396 & 0 & 0,409 & 2,923 & 37,345 & 0,698 & 0,022 & 81,31 \\
\hline BNIS & 0,15 & 0 & 2,14 & 6,40 & 19,42 & 1,34 & 0,04 & 42,98 \\
\hline
\end{tabular}

Table 3 . Maqashid Index Performance Ratio 2016

\begin{tabular}{lllllllll}
\hline Banks & $\begin{array}{l}\text { Maqashid Index } 1^{\text {st }} \text { (MI } \\
\text { 1) }\end{array}$ & (MI 2) & \multicolumn{2}{l}{ Maqashid Index $3^{\text {rd }}$} & & & \\
& $\mathrm{R} 1^{1}$ & $\mathrm{R}^{2}$ & $\mathrm{R}^{3}$ & $\mathrm{R}^{4}$ & $\mathrm{R}^{2}$ & $\mathrm{R}^{1}$ & $\mathrm{R}^{2}$ & R3 $^{3}$ \\
\hline BMI & 0,363 & 0,297 & 0,343 & 0,439 & 52,285 & 0,208 & 4,021 & 79,2 \\
\hline BSM & 14,763 & 0,014 & 0,552 & 1,182 & 29,669 & 0,566 & 0,016 & 71,417 \\
\hline BRIS & 0,040 & 0 & 3,94 & 1,41 & 37,214 & 0,862 & 0,04 & 64,722 \\
\hline BNIS & 2,26 & 0 & 2,26 & 6,08 & 19,95 & 1,32 & 0,04 & 73,33 \\
\hline
\end{tabular}




\section{Maqashid Index Performance Ratio $1^{\text {st }}$}

a. Education Grant $\left(\mathrm{R} 1^{1}\right)$

Calculation based on syariah index performance ratio trends in the form of educational grants in the year 2014 can be seen that in providing the highest educational aid or scholarships to employees, Bank Muamalat Indonesia (BMI) obtained. Meanwhile, it was followed by State Bank Negara Indonesia Syariah (BNIS), Bank Syariah Mandiri (BSM), and finally the Bank Rakyat Indonesia Syariah (BRIS). This trends ranking performance index ratio by the year 2015 had a high enough increase in the ratio from the previous period in the BRIS, namely $18,396 \%$, whereas BMI was still in a ratio of $0.2 \%$, was followed by BSM and BNIS. In the last period of 2016 increased ratio of happening in BSM $14,763 \%$, BRIS had decreased in a ratio that was far enough from the previous period of $0040 \%$, was followed by BMI and BNIS.

b. Reaserch $\left(\mathrm{R} 1^{2}\right)$

The results of calculation of the ratio of the performance index Trends during the years 2014-2016 only Bank Muamalat Indonesia and Bank Syariah Mandiri only charged for research, while Bank Rakyat Indonesia and Bank Negara Indonesia Syariah was not pay for research or $0 \%$.

c. Training / Instilling new skills and improvement (R13)

Based on the results of the calculation of the index performance trends cost ratio of training costs in the form of training for employees of BNIS years 2014-2016, remain consistent around the ratio of $2 \%$. While the period 2016, BRIS had increased the ratio of $3.94 \%$ from the previous year to about $1.04 \%$ and $0409 \%$, whereas BMI in the ratio $0703 \% 03431,715, \%, \%$, and the ratio of BSM $0681 \% 1,202 \%$ and $0552 \%$ in period in 2014-2016.

d. Publicity/Creating Awareness of Islamic banking $\left(\mathrm{R} 1^{4}\right)$

The results of the calculation of the performance ratio of the BNIS Maqashid Index continue to consistently increase publication costs from 2014 by $5.33 \%$, increasing to $6.40 \%$ and 2016 experiencing a slight decrease of $6.08 \%$. BMI obtained a ratio of $3.424 \%$ in 2016 continued to rise to $4.170 \%$ but in 2016 it dropped very drastically, namely $0.439 \%$. Likewise, BRIS, which was in third place with a ratio of $2.572 \%$, rose to $2.923 \%$ but dropped to a 1.41 ratio in 2016. BSM was at the lowest position in the acquisition ratio of $1.362 \%, 1.373 \%$ and in 2016 fell to $1.182 \%$

2. Maqashid Index Performance Ratio $2^{\text {nd }}$

Functional Distribution (R2 ${ }^{2}$ ), The results of the Maqashid Index performance ratio calculation for functional distribution for BMIs were able to maintain a ratio of around $50 \%$, namely $50.991 \%, 53.835 \%, 52.285 \%$ and was the highest performance ratio for the 2014-2016 period. Then the acquisition was ranked second by BRIS with a ratio of about $30 \% 31.715 \%, 37.345 \%, 37.214 \%$, third in the BSM performance ratio although it was still around $20 \%$ but continued to be able to increase up to $29.666 \%$ in the 2016 period, and BNIS was in the last order namely $16.43 \%$ in 2014 and continued to increase to 19.95 in 2016.

3. Maqashid Index Performance Ratio $3^{\text {rd }}$

a. Profitability $\left(\mathrm{R} 3^{1}\right)$

The results of the calculation of the BNIS profitability ratio were in the highest rank and able to maintain the ratio of around $1 \%$ in $2014-2016$, namely $1.13 \%, 1.34 \%$ and $1.32 \%$. Furthermore, in 2014 the second position was BMI with a ratio of $0.159 \%$, but in 2015 - 
2016 BRIS was in the second position with a ratio of 0.698 and $0.862 \%$. In the 2014 period BSM obtained a very low ratio of $0.034 \%$, but experienced an increase in the ratio value in the $2015-2016$ period of $0.545 \%, 0.566 \%$.

b. Personal Income/Redistribution of income \& wealt $\left(\mathrm{R} 3^{2}\right)$

The results of the maqashid index calculation in 2014 BRIS became the highest Islamic bank in collecting zakat funds whose performance ratio was obtained at $0.047 \% \%$, and in 2014 BNIS obtained $0.03 \%$, BMI $0.023 \%$ and the smallest was BSM which was $0.005 \%$. In 2015 BNIS received a value of $0.04 \%$ while BRIS dropped to $0.022 \%$, was followed by BSM $0.016 \%$ and the final BMI $0.003 \%$. In 2016, the BMI experienced a very high increase in the ratio value from the previous two years which was $4.021 \%$, BNIS was still at the ratio of $0.04 \%$, BRIS obtained a slight increase to $0.04 \%$, while BSM still obtained the smallest value of $0.016 \%$.

c. Investment in Real Sector (R3 $\left.{ }^{3}\right)$

In 2014 BRIS was in the top position in terms of obtaining maqashid index performance ratios in investment in the real sector which was $86.92 \%$, in the second place was $68.216 \%$ by BMI, then BSM with acquisition value of $54.819 \%$ and BNIS fourth in the ratio of $44.81 \%$. Although BRIS in 2015 was still in the first position in the acquisition of investment ratios, the value of the ratio dropped to $81.31 \%$, as did the BMI who were still in the second rank but experienced a decrease in the ratio value of $58.663 \%$, the third and fourth order were still BSM and BNIS namely 51.45\%, 42.98\%. Changes in position occurred in 2016, where BMIs became Islamic banks with the highest ratio of $79.2 \%$, BNIS was in second place with $73.33 \%$, and BSM was third in $71.417 \%$, while BRIS was in the last place in the acquisition the ratio value is $64.722 \%$.

Furthermore, in this study describe the performance of Islamic banks for each year based on the maqashid index. The following table presents the Sharia Maqashid Index of Islamic banking based on ratings during 2014-2016.

Tabel 4 . Rank of Islamic Banking based on Maqashid Index

\begin{tabular}{lllllll}
\hline Banks & 2014 & \multicolumn{3}{c}{2015} & \multicolumn{3}{c}{2016} \\
\cline { 2 - 7 } & MI & Rank & MI & Rank & MI & Rank \\
\hline BMI & 2,239 & 1 & 2,189 & 2 & 2,371 & 1 \\
\hline BSM & 1,788 & 3 & 1,809 & 3 & 2,181 & 2 \\
\hline BRIS & 2,224 & 2 & 2,411 & 1 & 2,082 & 3 \\
\hline BNIS & 1,702 & 4 & 1,724 & 4 & 2,052 & 4 \\
\hline
\end{tabular}

It can be seen that in 2014 BMI became the best Islamic bank in the performance of maqashid index with a ratio of $2.239 \%$, while BRIS was ranked second with a ratio of $2.224 \%$, third and fourth in rank was BSM and BNIS with a ratio of $1.788 \%, 1.702 \%$. In 2015 BRIS was ranked first as a sharia bank with the best maqashid performance of $2.411 \%$, was followed by BMI in the second place with a ratio of $2.189 \%$, third and fourth place still was occupied by BSM and BNIS with a ratio of $1.809 \%, 1.724 \%$. The last year of 2016 BMI became a sharia bank with the best maqashid performance of $2,371 \%$, while BSM managed to occupy the second position with a value of $2,181 \%$, then third and fourth was rank by BRIS $2,082 \%$, BNIS $2.052 \%$ 


\section{Conclusions}

The results of this study of four Islamic banks is being sampled, namely Bank Muamalat Indonesia, Bank Syariah Mandiri, Bank Rakyat Indonesia and Bank Negara Indonesia Syariah showed that the performance of each bank using ratio trends no able to realize high performance on all eight performance ratio. Each year the performance of Islamic banking trends index with different results, this shows the inconsistency of Sharia Bank to focus on the overall goal of Sharia. (Jazil and Syahruddin, 2013) the results showed that each of the calculated ratio will get the results vary from one Islamic bank to another. The largest-scale national Sharia banking to always focus on the purpose of the accord with Sharia muamalah (Hartono and Sobari, 2017). Islamic finance institutions are recommended to integrate policies that also reached the Maqasid al-Shariah (Khattak, 2018).

\section{References}

[1] Afif Muamar, A. S. A. (2017) 'Maqashid syariah', jurnal of Islamic Economic Lariba, 3(2), pp. 75-84.

[2] Ahmed, H. (2011) 'Citation for published item: Ahmed, Habib (2011) 'Maqasid alShari'ah and Islamic nancial products : a framework for assessment MAQÓØID ALSHARÔNAH AND ISLAMIC FINANCIAL PRODUCTS: A FRAMEWORK FOR ASSESSMENT', ISRA International Journal of Islamic Finance •, 3(1), pp. 149-160. Available at: http://www.isra.my/publications/journal-english/current-issues/volume-3june-2011.htmlTel: +44 .

[3] Antonio, M. S., Sanrego, Y. D. and Taufiq, M. (2012) 'An Analysis of Islamic Banking Performance: Maqashid Index Implementation in Indonesia and Jordania', Journal of Islamic Finance, 1(1), pp. 12-29. doi: 10.15604/ejef.2017.05.01.008.

[4] Bedoui, M. H. (2012) 'Shari'a', (January), pp. 1-12.

[5] Harningtyas, A. F. (2015) 'Developing Maqasid al-Shari_ah Index to Evaluate Social Performance of Islamic Banks_A Conceptual and Empirical Attempt[\#313846]303975.pdf', (1), pp. 5-64. doi: 10.1364/JOSAA.28.001243.

[6] Hartono, S. and Sobari, A. (2017) 'Sharia Maqashid Index As a Measuring Performance of Islamic Banking: a More Holistic Approach', Corporate Ownership and Control, 14(2), pp. 193-201. doi: 10.22495/cocv14i2c1p5.

[7] Jazil, T. and Syahruddin (2013) 'The Performance Measures of Selected Malaysian and Indonesia Islamic Banks based on the Maqasid al-Shari'ah Approach', Ijtihad, 7(2), pp. 279-301. Available at: http://ejournal.unida.gontor.ac.id/index.php/ijtihad/article/view/89.

[8] Khattak, M. A. (2018) 'Protection and Distribution of Wealth, Islamic Commercial and Financial Transactions: A Maqasid Al-Shariah perspective', European Journal of Islamic Finance, 0(10), pp. 1-8. doi: 10.13135/2421-2172/2570.

[9] Mohammed, M. O. and Razak, D. A. (2008) 'The Performance Measures of Islamic Banking Based on the', IIUM International Accounting Conference (INTAC IV), Putra Jaya Marroitt, 1967(June), pp. 1-17.

[10] Prasetyowati, L. A. and Handoko, L. H. (2016) 'Pengukuran Kinerja Bank Umum Syariah Dengan Maqasid Index dan Sharia Conformity And Profitability (SCNP)', Jurnal Akuntansi dan Keuangan Islam, 4(2), pp. 107-130.

[11] Puspitasari, N., Rukmana, D. H. and Sukarno, H. (2017) 'Analysis of Islamic Banking Efficiency Using Maqashid Shariah Approach ( Study on Islamic Banks in Indonesia and Malaysia )', 2(4), pp. 1-7. 
[12] Qasim, Y. R. et al. (2017) 'Measurement the Performance Levels of Islamic Banks in Jordan', Journal of Public Administration and Governance, 7(3), p. 75 . doi: 10.5296/jpag.v7i3.11451.

[13] Rabaa, B. and Younes, B. (2016) 'the Impact of the Islamic Banks Performances on Economic Growth: Using Panel Data', International Journal of Economics and Finance Studies, 8(1), pp. 1309-8055. doi: ISSN: 1309-8055.

[14] Salman Syed Ali, H. H. (2014) 'IRTI Working Paper Series Towards a Maqasid alShariah based Development Index', Islamic Research and Training Institute, 18, pp. 122. Available at: http://www.irti.org/English/Research/Documents/WP/WP-143518.pdf.

[15] Saoqi, A. A. Y. (2017) 'Analyzing The Performance of Islamic Banking in Indonesia and Malaysia: Maqasid Index Approach', Jurnal Ekonomi Islam, 8(1), pp. 29-50.

[16] Soleh, I. (2016) 'the Impact of Maqashid Syariah and Core', IV(10), pp. 872-880.

[17] Sudrajat, A. (2015) 'SYARIAH BERDASARKAN INDEKS MAQASID SHARI'AH ( Studi Kasus pada 9 Bank Umum Syariah di Indonesia Tahun 2015 )'.

[18] Towadi, M. (2017) 'The Application of Sharia Maqashid on the Protection of the Rights of Minority of Muslim Rohingya in Regional ASEAN (Indonesia-Malaysia)', Journal of Indonesian Legal Studies JILS, 2(21), pp. 43-54. 